
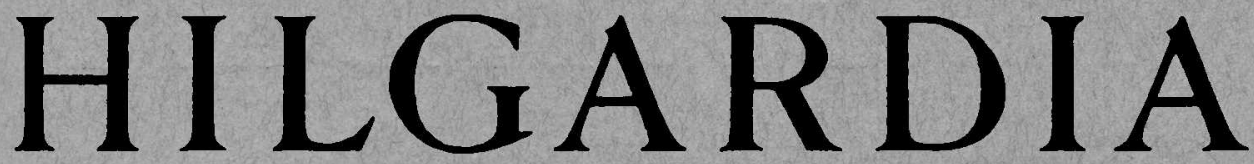

A Journal of Agricultural Science Publisbed by the California Agricultural Experiment Station

\title{
ETIOLOGY OF CEREAL ROOT ROTS IN CALIFORNIA
}

\author{
JOHN W. OSWALD
}

UNIVERSITY OF CALIFORNIA · BERKELEY, CALIFORNIA 


\section{This report...}

covers an investigation of the cereal root-rot complex in California. From 134 cereal fields (primarily wheat and barley) representing 20 counties, the following rootrotting fungi have been isolated:

Primary pathogenic fungi:

1. Helminthosporium sativum P., K. et B.

2. Fusarium roseum f. cerealis (Cke.) emend. Snyd. et Hans. (both Gibberella-and nonperithecium-producing clones)

3. Ophiobolus graminis Sacc.

4. Fusarium nizale (Fr.) Ces. emend. Snyd. et Hans. (first record in California as a root-rotting parasite)

Pathogenic fungi of occasional importance:

1. Pytbium graminicolum Subr. (first record in California)

2. Sclerotium rolfsii Sacc.

3. Rbizoctonia solani Kühn

Fungi of secondary importance:

1. W'ojnowicia graminis (McAlp.) Sacc. and Sacc.

2. Iusarium moniliforme Sheld. emend. Snyd. et Hans.

3. Fusarium roseum Lk. emend. Snyd. et Hans.

Gibberella-producing clones of Fusarium roseum $\mathrm{f}$. cerealis are commonly isolated from roots and crowns. Head blight, or kernel scabbing, does not seem to be caused by this fungus in California. Its absence is accounted for hy a lack of ascospore inoculum and by inadequate humidity at the time of heading.

Fields known to be infested by the primary pathogens are tabulated by counties. Each associated fungus is discussed, together with the symptoms it causes and its importance in the root-rot complex in California. 


\section{H I L G A R D I A}

A Journal of Agricultural Science Published by

the California Agricultural Experiment Station

\section{ETIOLOGY OF CEREAL ROOT ROTS IN CALIFORNIA'}

\section{JOHN W. OSWALD²}

\section{OCCURRENCE AND ECONOMIC IMPORTANCE OF FUNGI INVOLVED IN CEREAL ROOT ROT}

IN MOST of the major grain-producing regions of the world, fungus root rots ${ }^{3}$ have been and continue to be of primary economic importance. These are diseases of great complexity in that many different fungi are involved. A number of these are capable of attacking cereal crops in all stages of development; others are weak pathogens of only secondary importance; and many are totally saprophytic. Different pathogenic fungi may occur together in the same field and even in the same host plant. All induce somewhat similar symptoms. Only in take-all, caused by Ophiobolus graminis Sacc., are the symptoms distinctly characteristic. Foot rot, common root rot, crown rot, pink root, culm rot, and stalk rot are descriptive terms often used in connection with this complex of diseases, with which numerous parasitic fungi are associated. The seedling damage frequently encountered is usually referred to as seedling blight, regardless of the causal fungus.

The exact extent of loss brought about by root rot is difficult to ascertain, primarily because these diseases are often most severe under abnormal growth conditions, such as drought, excessive soil moisture, or a low level of nutrition; and because the symptoms on the roots and crowns may be inconspicuous even when the effect upon yield is material. In the Canadian prairie provinces, losses have been especially severe. Machacek (1943) ${ }^{4}$ reported for Manitoba alone an average annual loss of 12 per cent of the wheat crop from common root rot.

Little reference has been made to cereal root rots in California. Mackie (1923) reported the presence of take-all on wheat at Davis but concluded that the disease was of little consequence. Later (Mackie, 1931), he reported

\footnotetext{
${ }^{1}$ Received for publication July 28, 1949.

${ }^{2}$ Assistant Professor of Plant Pathology and Assistant Plant Pathologist in the Experiment Station.

3 The term root rot is used in this paper in a broad sense to include a rot of root, crown, basal-culm, and leaf-sheath tissues.

"See "Literature Cited" for citations, referred to in the text by author and date.
} 
Fusarium culmorum (W. G. Sm.) Sacc. var. leteius Sherb. to be common throughout the state as a cause of pink root of cereals. He suggested that this fungus, rather than $F$. graminearum Schw. (Gibberella zeae [Schw.] Petch), which is the common cause of seedling blight and scab in the eastern and middle western United States, was the important fungus in California. The latter species had not been reported in the state at that time as a cause of either seedling blight or kernel scab. He also listed $F$. roseum Lk. and $F$. avenaceum (Fr.) Sacc. as being present but questioned their proper identity. The only reference to the occurrence in California of $F$.graminearum, as well as of $F$. nivale (Fr.) Ces. emend. Snyd. et Hans. ${ }^{5}$ and species of Helminthosporium and Pythium on cereals, is in Smith's (1941) recent circular; this reference is based largely on the work reported herein.

\section{NEW NOMENCLATURE FOR FUSARIUM ISOLATES}

Because of the close relationship between the fusaria in Wollenweber's (1935) sections-Discolor, Roseum, Gibbosum, and Arthrosporiella-Snyder and Hansen (1945) have placed all species, varieties, and forms formerly included in these sections in the species Fusarium roseum Lk. emend. Snyd. et Hans. Isolates proved pathogenic to cereals are designated as F. roseum $\mathrm{f}$. cerealis (Cke.) Snyd. et Hans. Oswald (1949) has presented evidence along cultural and pathogenicity lines to substantiate this regrouping in his work with Fusarium isolates from California. The species $F$. roseum, as it is now constituted, or its form, $\boldsymbol{F}$. roseum f. cerealis, includes, therefore, many of the fusaria commonly associated with cereal root rots and designated previously under such species names as $F$. graminearum, $F$. culmorum, $F$. avenaceum, Fusarium scirpi Lamb et Fautr., Fusarium equiseti (Cda.) Sacc., and Fusarium sambucinum Fkl.

\section{FUNGI ISOLATED FROM ROOT-ROT-INFECTED CEREALS}

Investigation of the problem in California began in 1939, when a severe root rot of both barley and wheat was discovered to be widespread in the Montezuma Hills section of Solano County. Since that time, root rot has been found generally widespread in the state on wheat and barley and is increasing in those areas continually cropped to grain. Up to the present time, numerous isolations have demonstrated root rot in 134 fields representing 20 counties. This disease constitutes a major problem in the Montezuma Hills, the Sacramento-San Joaquin Delta, the Montpelier region of Stanislaus County, and some areas in Fresno, Tulare, and Kings counties. It is primarily a disease of wheat and barley, but oats and corn are also attacked by certain of the fungi.

Isolations from diseased cereal plants in all stages of growth and subsequent testing of the resulting fungi for parasitism on wheat and barley have shown that most of the principal root-rot pathogens common in other areas occur in California (Oswald, 1947). These include Helminthosporium sativum P., K. et B., Ophiobolus graminis, Gibberella (F'usarium) roseum f. cerealis, $F$. nivale, and Pythium graminicolum Subr. This is the first record of the occur-

\footnotetext{
${ }^{5}$ Although Smith used the bipomial Fusarium niveum, it is clear that $F$. nivale was intended, since reference was made to my isolation studies.
} 
rence in California of $F$. nivale and $P$. graminicolum as root-rotting parasites of cereal crops. It is also the first record of Gibberella-producing clones of $\boldsymbol{F}$. roseum $\mathrm{f}$. cerealis in the state.

Table 1 summarizes the results of all isolations and divides the fungi into four groups based on their parasitic tendencies. It is evident that Helminthosporium sativam and Fusarium roseum f. cerealis are the principal pathogens in the state. With the exception of the occasional attack of oats by this Fusarium, root rot is of primary importance only on barley and wheat.

TABLE 1

FUNGI ISOLATED FROM CEREAL CROPS AFFECTED WITH ROOT ROT

\begin{tabular}{|c|c|c|c|c|c|}
\hline \multirow{2}{*}{ Fungus } & \multicolumn{5}{|c|}{ Number of fields from which isolated } \\
\hline & Total & Wheat & Barley & Oats & Corn \\
\hline \multicolumn{6}{|l|}{ Pathogenic fungi of primary importance: } \\
\hline Helminthosporium sativum................. & $\cdot 35$ & 19 & 16 & 0 & 0 \\
\hline 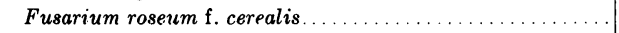 & 67 & 32 & 29 & 5 & 1 \\
\hline 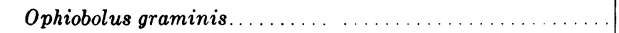 & 17 & 9 & 8 & 0 & 0 \\
\hline 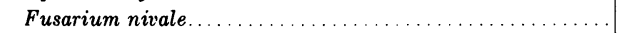 & 15 & 5 & 10 & 0 & 0 \\
\hline \multicolumn{6}{|l|}{ Pathogenic fungi of occasional importance: } \\
\hline Pythium graminicolum................ & 2 & 0 & 2 & 0 & 0 \\
\hline Sclerotium rolfsii....... & 4 & 0 & 4 & 0 & 0 \\
\hline Rhizoctonia solani. & 13 & 7 & 5 & 1 & 0 \\
\hline \multicolumn{6}{|l|}{ Weakly parasitic fungi of secundary importance: } \\
\hline Wojnowicia graminis.... & 18 & 8 & 9 & 1 & 0 \\
\hline Fusarium moniliforme. .................. & 7 & 1 & 2 & 0 & 4 \\
\hline Fusarium roseum........ & 28 & 10 & 13 & 5 & 0 \\
\hline \multicolumn{6}{|l|}{ Fungi nonpathogenic to cereals: } \\
\hline Fusarium oxysporum.... & 18 & 5 & 10 & 2 & 1 \\
\hline Fusarium solani........ & 4 & 2 & 2 & 0 & 0 \\
\hline Colletotrichum sp...... & 15 & 5 & 10 & 0 & 0 \\
\hline Phoma terrestris........ & 3 & 0 & 2 & 0 & 1 \\
\hline
\end{tabular}

The distribution of fields known to be infested with the four principal parasitic fungi is presented in table 2 . The information contained in this table is not the result of a formal survey of the state for these fungi but, rather, is a report of the locations of the root-rot-infested fields to which my attention has been called to date. Twenty counties are included. Helminthosporium sativum, occurring in 14 counties, and Fusarium roseum f. cerealis in 15, are the most widespread. The majority of these represent fields in which root rot has been severe. A thorough survey of the state would undoubtedly reveal that these same fungi occur in many other localities.

The etiology of cereal root rot in California is complex in that isolations from many fields demonstrated more than one pathogen to be involved. In some instances, as many as three distinct parasitic fungi were located in the same field and occasionally in the same host plant. Helminthosporium sativum, for instance, has been recovered from 35 fields. It occurred alone in 11 fields; with $F$ usarium roseum f. cerealis in 13 fields; with Ophiobolus graminis in 5 fields; and with $F$. nivale in 4 . In 2 fields, $H$. sativum, $F$. roseum f. cerealis, and 0 .graminis were found commonly in the same diseased plant. Thus, ap- 
proximately 40 per cent of all fields found to be infested with $H$. sativum also carried $F$. roseum f. cerealis. The close association of these two fungi simulates common root rot in Canada (Simmonds, 1941). There, however, the Culmorum type of this Fusarium was most consistently involved in the complex, whereas in California, the Gibberella-producing clones predominate.

TABLE 2

CALIFORNIA FIELDS KNOWN TO BE INFESTED WITH PRIMARY
OEREAL ROOT-ROT FUNGI*

(As of July 1949)

\begin{tabular}{|c|c|c|c|c|}
\hline \multirow{2}{*}{ County } & \multicolumn{4}{|c|}{ Fields found to be infested with: } \\
\hline & $\begin{array}{c}\text { Helminthosporium } \\
\text { sativum }\end{array}$ & $\begin{array}{l}\text { Fusarium roseum } \\
\text { f. cerealis }\end{array}$ & $\underset{\text { Ophaminis }}{\text { Ophioblus }}$ & $\begin{array}{c}\text { Fusarium } \\
\text { nivale }\end{array}$ \\
\hline \multicolumn{5}{|l|}{ Sacramento Valley: } \\
\hline Tehama........... & . & 1 & . & . \\
\hline Butte................. & 1 & 1 & . & . \\
\hline Sutter................ & 1 & 5 & 1 & 1 \\
\hline Yolo................ & 4 & 12 & 3 & 2 \\
\hline Sacramento............. & . & 4 & 1 & . \\
\hline Solano...................... & $\ddot{17}$ & $24 \dagger$ & 5 & 5 \\
\hline \multicolumn{5}{|l|}{ San Joaquin Valley: } \\
\hline San Joaquin ............. & 1 & 5 & $\ldots$ & $\ldots$ \\
\hline Merced.$\ldots \ldots \ldots \ldots \ldots \ldots$ & .. & 1 & $\begin{array}{l}\cdots \\
\cdots\end{array}$ & $\begin{array}{l}\cdots \\
\ldots\end{array}$ \\
\hline Stanislaus. . . . . . . . . . & $\ddot{2}$ & 2 & $\ddot{3}$ & $\ddot{5}$ \\
\hline Kings $\ldots \ldots \ldots \ldots \ldots \ldots$ & . & 4 & . & .. \\
\hline Fresno................... & 1 & 1 & . & .. \\
\hline Kern................. & 1 & . & . & . \\
\hline \multicolumn{5}{|l|}{ Coastal region: } \\
\hline Alameda................ & 1 & . & . & . \\
\hline Contra Costa.............. & 1 & 1 & . & . \\
\hline San Mateo................ & . & 1 & . & . \\
\hline San Luis Obispo.......... & 1 & $\ddots$ & . & 1 \\
\hline \multicolumn{5}{|l|}{ Southern California: } \\
\hline Riverside.......... & 2 & 2 & 3 & 1 \\
\hline Los Angeles.............. & . & 3 & 1 & . \\
\hline San Diego................ & 1 & . & . & .. \\
\hline Imperial................. & 1 & . & . & . \\
\hline Total: Fields............ & 95 & 67 & 17 & 15 \\
\hline Counties............ & 14 & 15 & 7 & 6 \\
\hline
\end{tabular}

* This table does not represent a thorough survey of the state but rather is a report of locations of the root-rotinfested fields which $I$ have encountered to date.

$\dagger$ Gibberella stage of Fusarium roseum $\mathrm{f}$. cerealis found in the field.

\section{PATHOGENIC FUNGI OF PRIMARY IMPORTANCE}

Under California conditions the four primary pathogenic fungi, in their order of apparent economic importance, are Helminthosporium sativum, Fusarium roseum f. cerealis, Ophiobolus graminis, and F. nivale.

Helminthosporium sativum. This fungus has long been known in the eastern United States as a cause of a root rot in wheat and in California as the cause of barley spot blotch (Mackie, 1931). That it undoubtedly has been active in the state as a root-rot parasite for some time is indicated by isolation studies which have shown it to be a common and widespread root-rot pathogen of barley and wheat. It has not been observed attacking oats. 
Diseased wheat seedlings (fig. 1) are characterized first by a tan to darkbrown discoloration of the coleoptile, accompanied by a stunting and yellowing of the upper part of the plant. Soon the culm and entire base become infected and discolored, the plant often dying at this stage (fig. 2). In severely infested soil, many of the seedlings are killed before they emerge. The plants

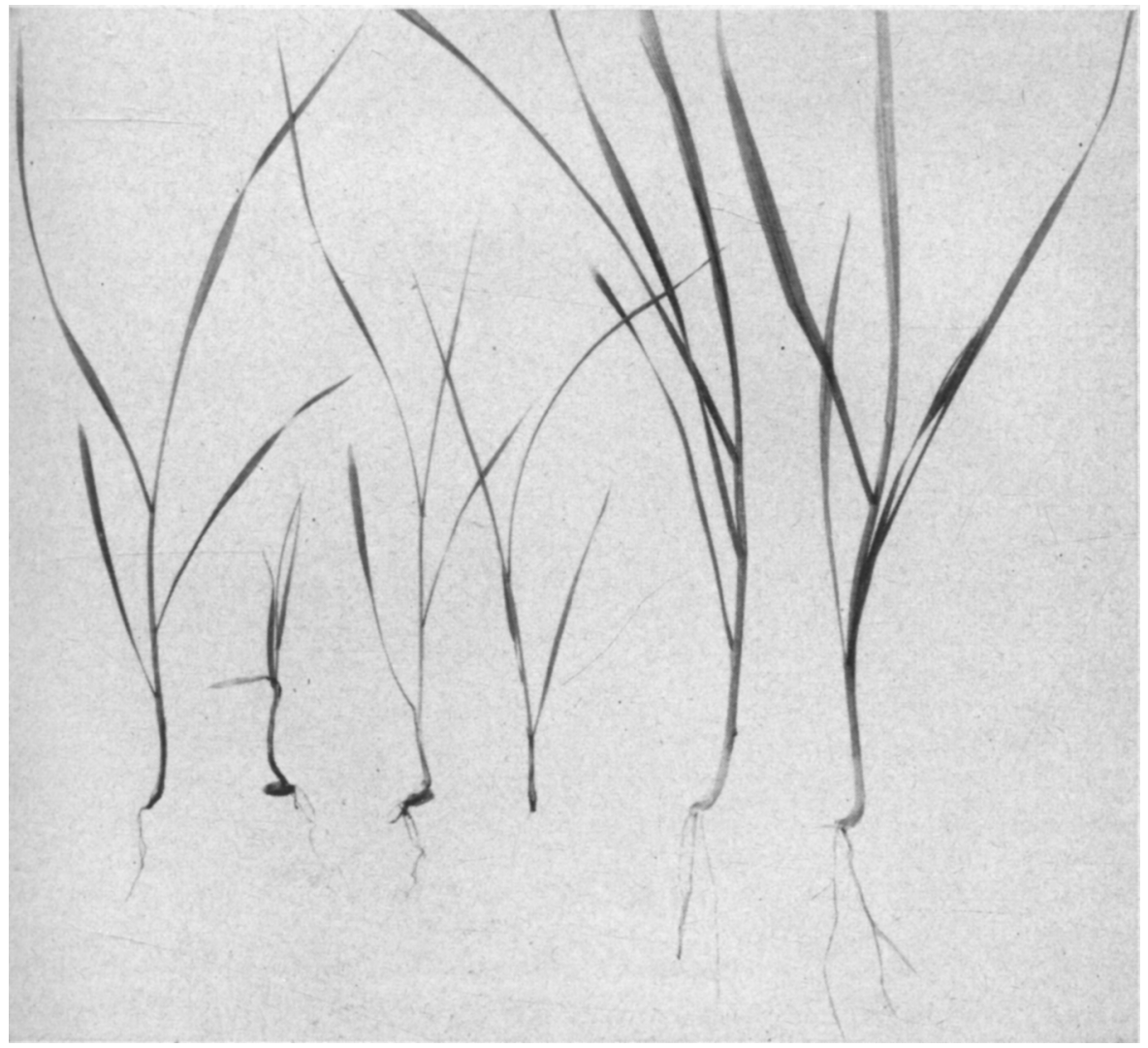

Fig. 1. Four two-week-old wheat seedlings blighted by Helminthosporium sativum (left), together with two healthy seedlings (right). Note the stunting and the intense dark coloration of the crowns of the diseased seedlings.

that survive the early attack or those that are infected at a later stage may continue to maturity but, in their weakened condition, may produce only partially filled heads with shriveled grain. On the older plants, the disease is spoken of as a foot or culm rot. The entire crown of such plants is brown to brownish-black in color and in most cases is badly rotted. The subcrown internode is often the portion of the plant most severely attacked. When this is destroyed, the plant can no longer draw on its seminal root system; its vigor and yielding potential are thus materially affected. The roots are relatively free from attack by this fungus. 
Plants infected with Helminthosporium sativum usually cannot be distinguished from those attacked by Fusarium or Pythium species. Isolations are necessary to identify the fungus involved. Occasionally under wet conditions, $H$. sativum produces conidia on the diseased tissues ; this is uncommon, however, under field conditions in California.

Helminthosporium sativum has been found in 35 different wheat and barley fields representing 14 counties. It is often intimately associated with Fusarium

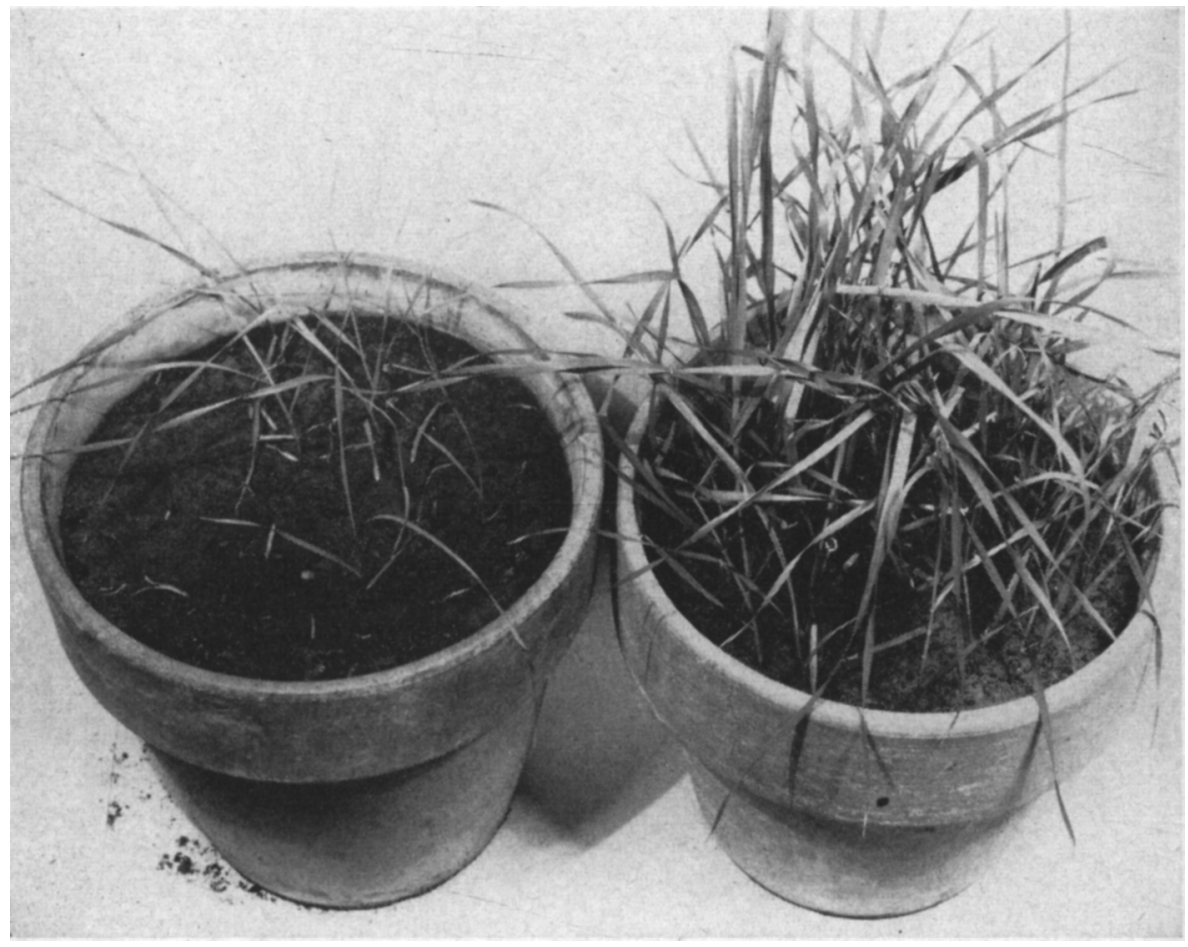

Fig. 2. Seedling blight of wheat caused by Helminthosporium sativum. Soil in the pot on the left was infested with $H$. sativum; on the right is the uninoculated check, 3 weeks after planting.

roseum f. cerealis, 40 per cent of all isolations yielding both fungi. In many cases both are present in the same plant. Isolations showed that in this association, Helminthosporium was more prominent in the seedling-blight phase of the disease than the Fusarium, but later in the season with older plants, the reverse was true. In one field, isolations from plants up to a month old consistently yielded $H$. sativum, while later isolations from plants in the same field yielded primarily the Fusarium. Yet when the two organisms were separated, each was capable of producing both seedling blight and root rot of older plants.

Helminthosporium sativum is apparently more active during the rainy winter months when the barley and wheat are in the seedling stage, because 
it is favored by high soil moisture (McKinney, 1923; Dickson, 1946). On the other hand, low soil moisture (Dickson, 1923) is reported likely to increase infection by Fusarium roseum f. cerealis.

Fusarium roseum f. cerealis (Gibberella roseum f. cerealis). Although not previously reported, the Gibberella clones of this fungus undoubtedly have been present in California since at least 1932, judging from a study of an old fungus culture made available to me. In 1932 , Leach ${ }^{6}$ isolated from diseased barley plants a fungus which was thought then to be $F$. graminearum. It proved to be severely pathogenic on wheat and barley seedlings, but its identity was not definitely established at that time. F. culmorum var. leteius (now considered synonymous with $F$. roseum f. cerealis) had been reported earlier as the widespread cause of root rot in the state (Mackie, 1931). Isolation studies now indicate that the Gibberella-producing clones are the most common in California except in the Sacramento-San Joaquin Delta.

In the present studies, Fusarium roseum f. cerealis was first isolated in 1939 from both barley and wheat affected with root rot in the Montezuma Hills in Solano County. Since then, it has been found in other fields in other counties, often in association with Helminthosporium sativum. Severe infestations also occur in certain fields in Fresno, Kings, and Tulare counties.

The symptoms produced on wheat and barley seedlings and on older plants (fig. 3) are practically indistinguishable from those described for Helminthosporium sativum. In general, the latter fungus is more severe on young seedlings, producing darker-colored lesions. Isolations, however, are necessary to ascertain which fungus is present. Occasionally, the Fusarium produces orange- to salmon-colored sporodochia on the basal nodes of infected plants.

In fields where severe damage has been previously experienced with wheat and barley, oats have been unaffected by the Gibberella-producing clones of this Fusarium. In the greenhouse, with heavy artificial inoculation, oats may become infected, but even there seem to have a high tolerance to the fungus. A field rotation with oats generally constitutes a practical control measure.

Seedling blight of corn caused by this fungus is common in the corn belt (Dickson, 1947). Its apparent absence in California may be explained by the facts that (1) corn is infrequently planted in older nonirrigated grain land where one might expect the concentration of Fusarium to be highest; and (2) corn is usually planted in California in late spring or early summer, in warm soil, a condition unfavorable to the seedling blight of corn (Dickson, 1923), caused by this fungus.

In the eastern United States, scab or the blighting of the heads of barley and wheat is an important phase of the disease. It is quite severe, especially when both temperature and humidity are high during the blossoming period. No head blight, or kernel scabbing, has been found in California even in fields known to be badly infested with the fungus. This absence of scab is probably due to a lack of favorable environmental conditions during the flowering period of the grain. For example, when the grain in the Montezuma Hills area is in the heading stage, the relative humidity is generally too low for infection. However, in 1941, though much of the early-planted barley headed during

\footnotetext{
${ }^{\circ}$ Unpublished data made available to me by Dr. L. D. Leach, University of California, Davis, California.
} 
late spring rains, no scab infection ensued. Perhaps another explanation that may be offered for the absence of scab is the lack of ascospore inoculum in the spring. In the East, where wheat scab is common, there is usually an abundance of perithecia (Gibberella) present on the old corn and wheat stubble. Numerous examinations of diseased plants and decaying stubble in badly infested fields in California have been made in an effort to find this perithecial stage.

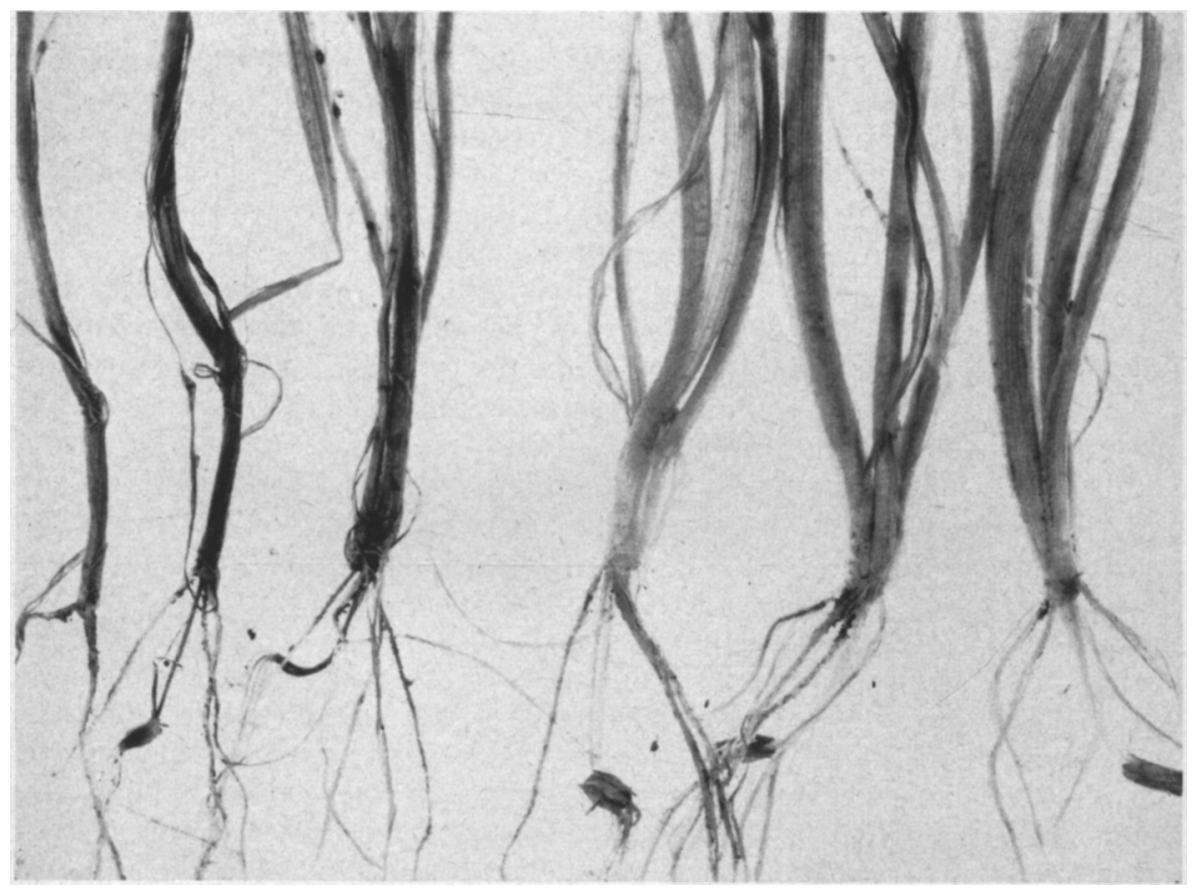

Fig. 3. Root rot of barley caused by Fusarium roseum f. cerealis, 60 days after planting. Three plants on the left are diseased; three on the right are healthy. Note shrunken condition and the brown discoloration extending up the culm.

It was observed in only one instance, when a small cluster of perithecia was found on barley stubble in the Montezuma Hills.

Just why the perithecia so seldom develop in the field is not thoroughly understood. It might be supposed that the strains of the organism commonly present in California are incapable of producing perithecia. Yet, in greenhouse pathogenicity trials on wheat, mature perithecia were produced on the basal parts of the older diseased plants. They occurred superficially in clumps on the base of the culm at the soil level. A few clusters of the fruiting bodies were also found attached to the crown roots under the soil level: Probably the absence of perithecia under field conditions can be explained both on a moisture and temperature basis. When soil moisture is high in the winter and early spring, the temperatures are ordinarily too low for perithecium formation. On the other hand, when the temperatures are higher in the late spring and summer, there is a lack of sufficient atmospheric moisture. 
Though nonperithecium-forming clones of this Fusarium-the kind described by Mackie (1931) under the name of $F$. culmorum var. leteius-were earlier considered to be a common cause of root rot throughout the state, these studies have not borne out this view. Clones of this type are, however, of particular importance in such highly organic soils as the peat soils of the Sacramento-San Joaquin Delta, where they apparently flourish saprophy-

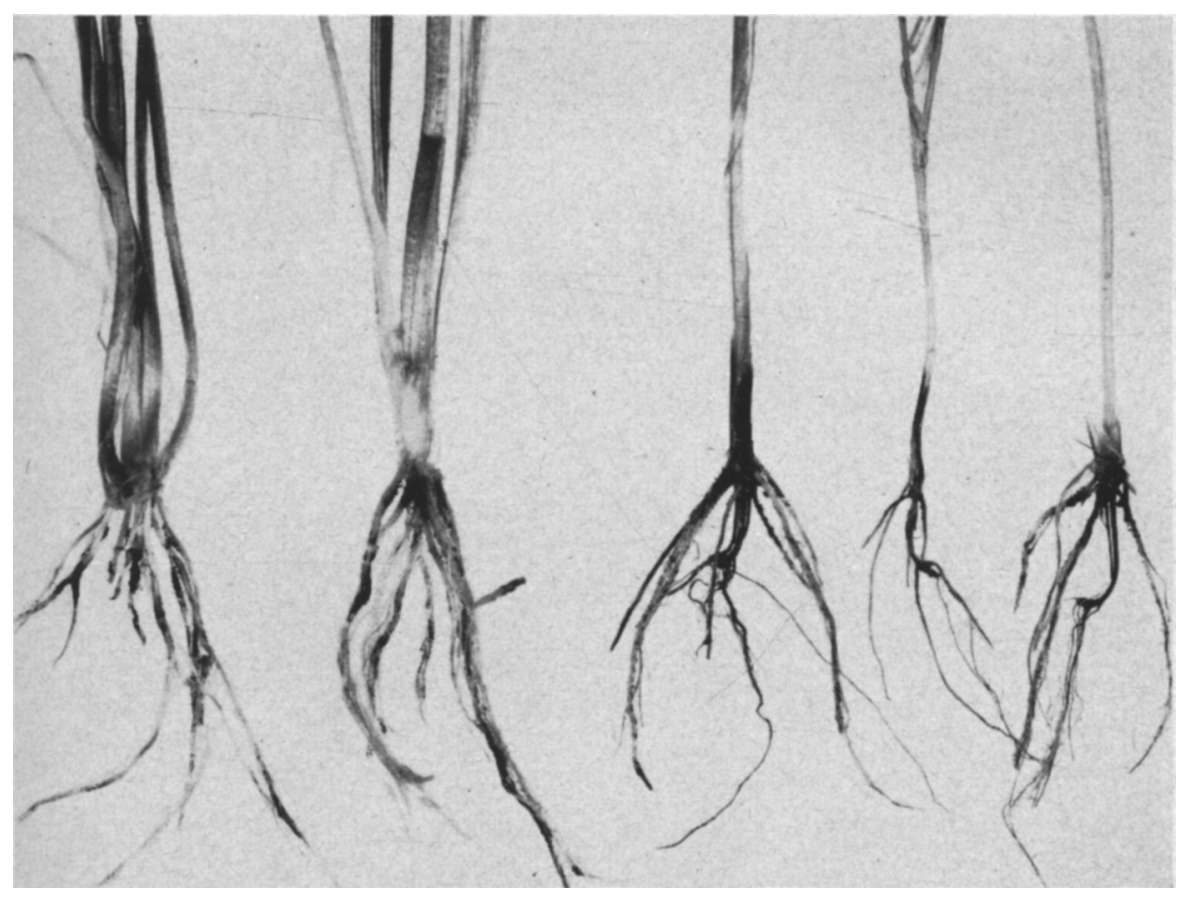

Fig. 4. Take-all of wheat caused by Ophiobolus graminis. The three plants at the right are diseased. These plants were grown in artificially infested soil in the greenhouse and harvested at the age of 2 months. Note the black discoloration of the crown and the absence of tillering as compared to the noninoculated check plants on the left.

tically. They differ from the Gibberella-producing clones further in that they occasionally cause root rot of oats. Such a situation was especially severe in 1948 on oats in the Sacramento Valley.

Ophiobolus graminis. Mackie (1923) first reported the presence in California of take-all, caused by Ophiobolus graminis. He found infected plants growing at Davis and reported the disease in other areas of the state. Since that time, there has been no mention of take-all in California except for the reference by Smith (1941) previously noted (page 448).

In these studies, Ophiobolus graminis was first isolated from diseased wheat specimens from Riverside County in 1941 and since has been located in a total of 17 fields in 7 counties. Certain fields in the Montpelier region of Stanislaus County are badly infested, as are a few in Riverside and Los Angeles counties. A severe spot of take-all occurs on the University Farm at Davis. In 
the Montezuma Hills, O. graminis, though present, plays a secondary role to the other more common pathogenic fungi already discussed.

Take-all differs from the root rots caused by the other fungi in that the symptoms are characteristic and easily recognized. Usually the plants survive the seedling stage with little obvious damage. At about six weeks, the plants

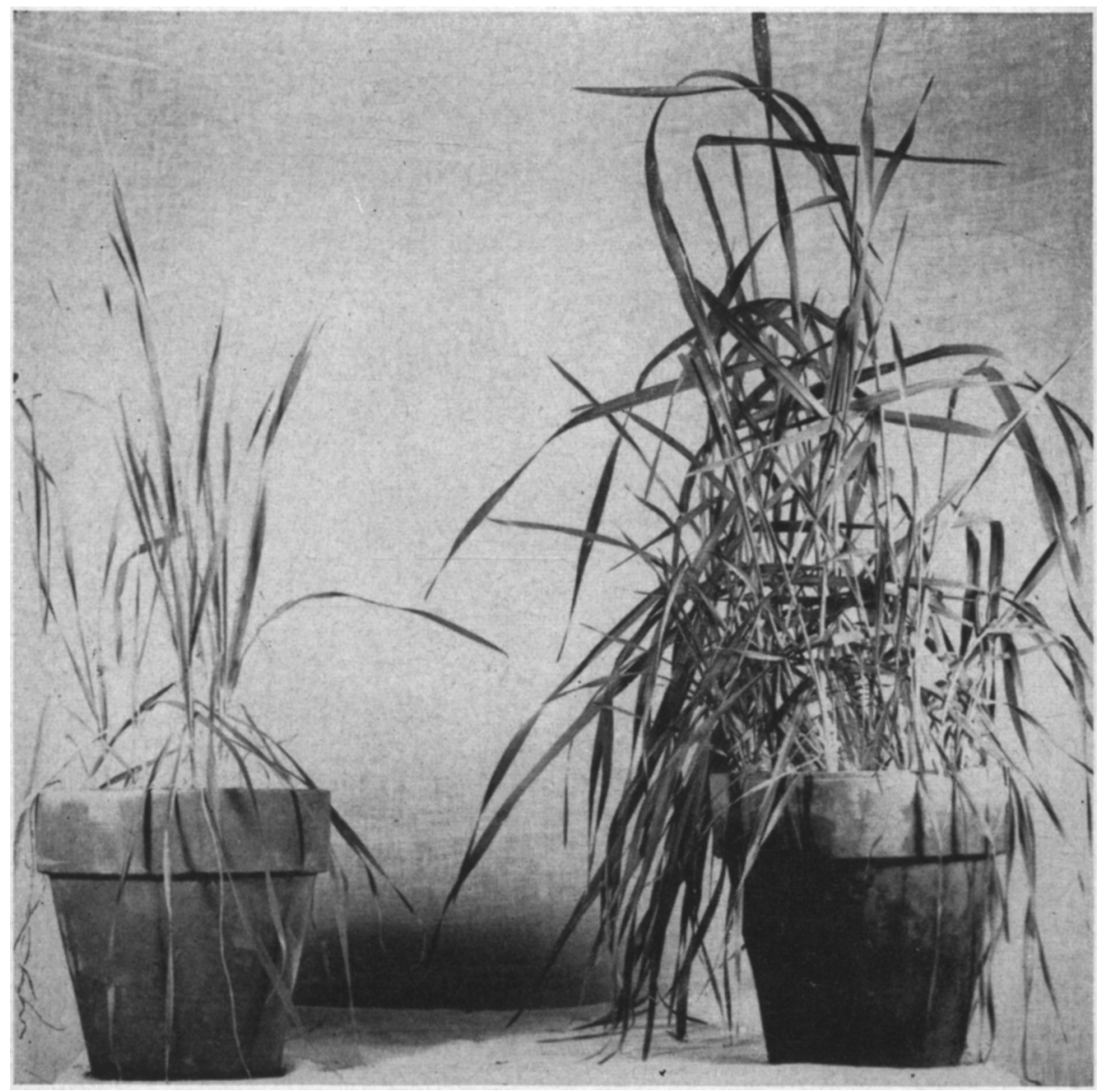

Fig. 5. Take-all of 3-months-old wheat caused by Ophiobolus graminis. The wheat in the left pot is growing in artificially inoculated soil. The pot on the right is the uninoculated check. Note the severe stunting.

show evidence of infection, appearing stunted with a marked reduction in tillering. Severe rotting of the roots, a shiny black discoloration of the crown and lower culm, and a dark mat of fungus growth between the basal leaf sheath and culm are all distinguishing features (figs. 4 and 5). In severe cases, the plants shrivel and die at this stage. Ordinarily they head prematurely with white empty spikes. The disease is usually localized in the field.

The perithecia of Ophiobolus graminis are black and flask-shaped and have a definite beak. Ordinarily they form in the culms near the crown, with the 
beaks protruding through the leaf sheath (fig. 6). Though they consistently develop on plants inoculated in the greenhouse, perithecia have never been observed in the field in California. This may be due to insufficient moisture in the surface layer of soil as the plants mature.

Take-all is generally considered a wheat disease though, in California, it has proved to be equally severe on barley. Suneson and Oswald (1948) have demonstrated that oats and rye are very tolerant to take-all and are of great value in a rotation program for reducing infection of barley or wheat.

Fusarium nivale. Of the four principal root-rot pathogens in California, Fusarium nivale, the snow-mold fungus, is of the least consequence and usually occurs in association with other more active parasites. It has been

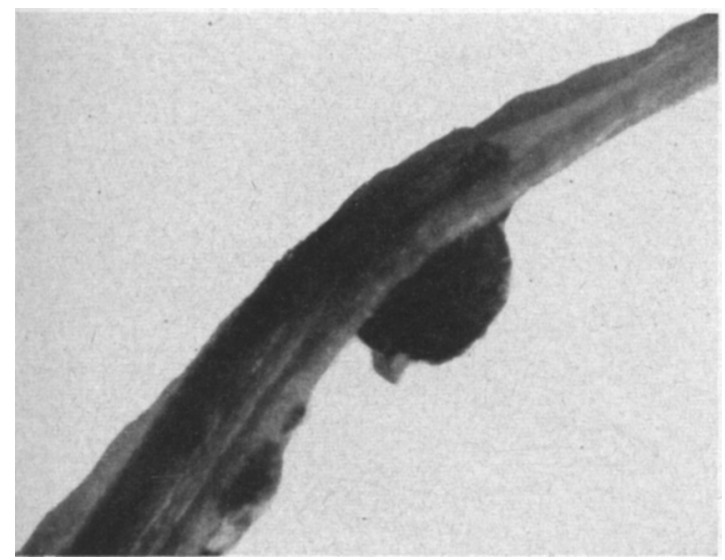

Fig. 6. Perithecium of $O p h i$ obolus graminis with beak protruding through leaf sheath $(\times 60)$. Produced on the base of a wheat plant grown in the greenhouse in naturally infested soil from Stanislaus County.

isolated only from the basal portions of older diseased plants. Diseased barley and wheat from 15 fields in 6 counties have yielded $F$. nivale.

Tests have shown it to be capable in itself of causing seedling damage on wheat and barley (fig. 7), a fact which indicates that its role is more than a secondary one.

This fungus, under continued moist conditions-for example, under a blanket of snow-is known to attack leaf and crown tissues of cereals, covering them with a moldy growth of mycelium and conidia, known as snow mold. Such symptoms on barley and wheat have not been observed in the state, though the snow-mold disease has been found on lawn grass on several occasions during very moist winters.

The ascigerous stage of this fungus, Calonectria graminicola (Berk. and Br.) Wr., has not been observed.

\section{PATHOGENIC FUNGI OF OCCASIONAL IMPORTANCE}

Pythium graminicolum. In the wet spring of 1938, certain barley fields in the foothills of the east side of the San Joaquin Valley near Montpelier, in Stanislaus County, were badly damaged by root rot. The stands were poor and the surviving plants were weakened, with only partially filled heads. 
Isolation and pathogenicity studies showed Pythium graminicolum ${ }^{7}$ to be the cause of the disease (fig. 8 ). Since that time, this fungus has been observed in only one other case, again associated with high moisture conditions.

Sclerotium rolfsii. In California, Sclerotium rolfsii Sacc. is rather widespread in the Sacramento and northern San Joaquin valleys and occurs in a few other localities. It causes much damage to sugar beets and some losses in beans, tomatoes, and other summer-irrigated crops. In four instances it has been observed attacking barley.

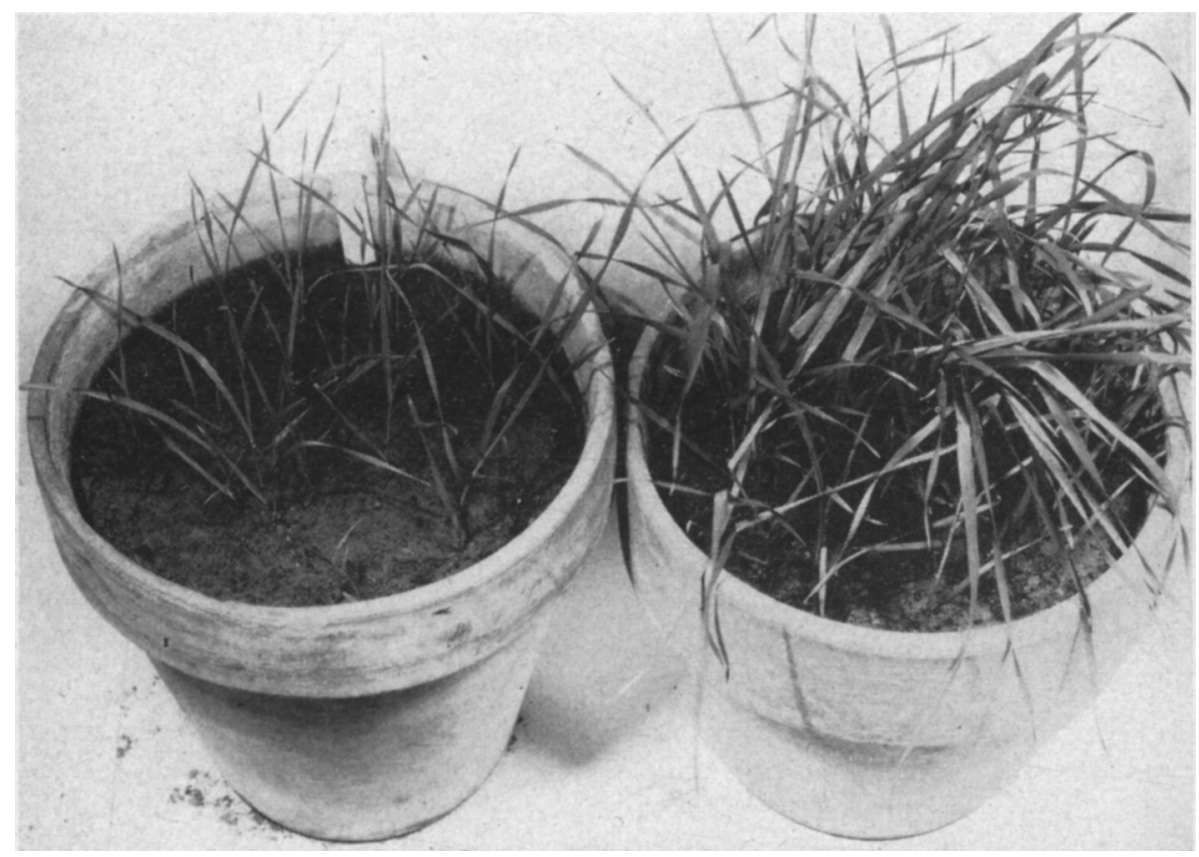

Fig. 7. Seedling blight of wheat caused by Fusarium nivale. Seedlings in the left pot are growing in soil artificially infested with the fungus; the pot on the right is the uninoculated check. The plants are approximately 3 weeks old.

Sclerotium rolfsii is most active under high temperature conditions with adequate soil moisture. In California, cereals are generally planted in late winter and early spring; the surface soil is usually dry before the advent of the high summer temperatures. No damage attributable to $S$. rolfsii has been observed on grains during this normal growing season. For this reason, winter-planted barley is considered a favorable rotation crop in fields known to be infested with this organism. Some infection has been observed in fields of late spring-planted barley when high temperatures were accompanied by late unseasonal rains. In one instance, a field of barley, summer-planted and irrigated, was severely damaged by S. rolfsii.

\footnotetext{
${ }^{7}$ I am indebted to Dr. John T. Middleton, University of California, Riverside, California, for the identification of this fungus.
} 
The fungus causes a rotting of the roots and a brown discoloration of the lower culm. Often accompanying these symptoms are dwarfing, reduction of vigor, and, in severe cases, complete killing. In the field, the characteristic mustard-seed-like sclerotia of Sclerotium rolfsii oceur only sparsely on infected barley. Under high moisture conditions in the greenhouse, however, they form abundantly around the crowns of the plants.

Rhizoctonia solani. Rhizoctonia solani Kühn is reported in some areas to be associated with the cereal root-rot complex. Sprague (1947) found that it

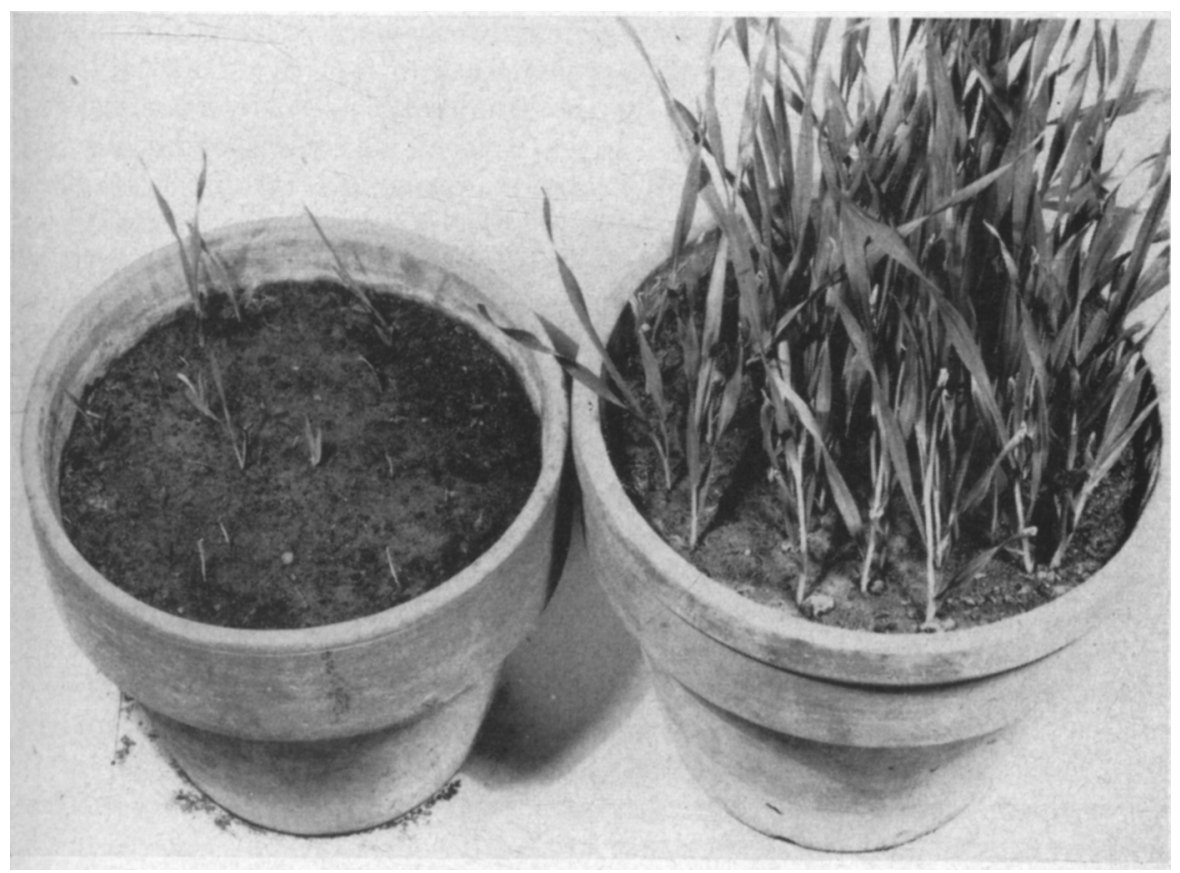

Fig. 8. Seedling blight of barley caused by Pythium graminicolum, 3 weeks after planting. Soil in the pot on the left is infested with $P$. graminicolum; on the right is the uninoculated check.

accounted for nearly 4 per cent of all fungi isolated from roots of Gramineae in the northern part of the western United States from 1940 to 1947. He segregated five strains of $R$. solani on a pathogenicity basis, ranging from virtually nonparasitic to extreme virulence on most of the Graminae.

In California, this fungus has been most frequently encountered in the Montezuma Hills of Solano County. It apparently plays a contributing role to the damage caused by some of the more important cereal parasites like Helminthosporium sativum, Fusarium roseum f. cerealis, and Ophiobolus graminis. Because it is the predominant fungus in a few fields, Rhizoctonia solani, in this paper, is considered a fungus of occasional importance. In pureculture inoculation studies, $R$. solani on wheat causes a browning of the cortical areas of the roots and crown and, in severe cases, premature death. No attempts were made to separate races. 


\section{WEAKLY PATHOGENIC FUNGI OF SECONDARY IMPORTANCE}

In this group are included the fungi which are frequently associated with the important pathogens but which, by themselves, are capable of inducing only slight damage on older, more mature plants previously weakened by disease or other causes. Their role may be that of invading the plant tissues as a secondary parasite and of assisting in the weakening and eventual collapse of the plant.

Wojnowicia graminis. In 18 fields, primarily wheat and barley, this fungus was found associated with root rot. Wojnowicia graminis (McAlp.) Sacc. and Sacc., according to Dickson (1947), occurs commonly in association with takeall. In California, it has been commonly associated with the root rot induced by Helminthosporium sativum and Fusarium roseum f. cerealis. Tests show this fungus to be only weakly parasitic on older wheat and barley plants.

Fusarium moniliforme. Fusarium moniliforme Sheld. emend. Snyd. et Hans. is common in California as the cause of Fusarium ear rot of corn and is also involved in seedling blight of corn and milo. In only three cases has it been isolated from wheat and barley; in each instance it was in association with Fusarium roseum f. cerealis. Isolates that showed moderate parasitism on corn and milo seedlings had little effect on wheat or barley. A slight discoloration of the coleoptile was the only evidence of infection.

Fusarium roseum. Frequently associated with cereal root rots as secondary or weak parasites are isolates of Fusarium roseum. Pathogenicity trials have demonstrated that these isolates range from slightly parasitic to saprophytic.

The principal types encountered are those cultures previously grouped by Wollenweber (1935) in the section Gibbosum under such names as Fusarium scirpi, $F$. scirpi var. acuminatum, and $F$. equiseti, and, to a lesser extent, his $F$. sambucinum with its varieties and forms. In California, these types of $F$. roseum have been recovered from 28 fields and in all instances were of only secondary importance.

\section{SAPROPHYTIC FUNGI ASSOCIATED WITH CEREAL ROOT ROTS}

After the diseased portions of plants affected with root rot are completely invaded and killed by the primary pathogens, a host of saprophytic soil fungi and bacteria follows. Advance margins of diseased tissues are used for making isolations, this technique being adopted in order to obtain the parasites and eliminate the saprophytic organisms. But even when the surface is sterilized with mercuric chloride, a large percentage of saprophytic fungi are recovered in these isolations.

The saprophytic fungus most commonly encountered in association with cereal root rots was Fusarium oxysporum Schlt. emend. Snyd. et Hans. It was obtained on 18 occasions; it frequently occurs as a saprophyte in the cereal crown, root, and culm tissues previously killed by pathogenic fungi. No isolate of $F$. oxysporum with any parasitic tendency toward cereals was found.

A Colletotrichum species approximating C. graminicolum (Ces.) Wils., but never identified as such, has been isolated twelve times from barley and 
wheat. It always occurred in connection with known root-rot parasites. Neither wheat nor barley grown in soil infested with this fungus alone showed any injury.

Fusarium solani (Mart.) App. et Wr. emend. Snyd. et Hans. and Phoma terrestris Hans. have been isolated occasionally from crown tissues of wheat and barley. Each appears to play only a saprophytic role in the cereal root-rot complex.

\section{SUMMARY}

In California, root rots of cereal crops are widespread and are of particular importance in those areas continuously cropped to grain. They constitute a major problem in wheat and barley in the Montezuma Hills of Solano County, in the Sacramento-San Joaquin Delta, in the Montpelier region of Stanislaus County, and in certain localities in Fresno, Tulare, and Kings counties.

The etiology of this group of related diseases has proved to be complex. Isolations over a six-year period from cereals affected with root rot, and subsequent testing of the resulting fungus cultures for parasitism on wheat and barley, have shown that most of the root-rot pathogens common in other regions also occur in California. Widespread on wheat and barley (in the order of their apparent economic importance) are Helminthosporium sativum, Fusarium roseum f. cerealis (Gibberella roseum f. cerealis), Ophiobolus graminis, and $F$. nivale. These four fungi, the most important pathogens in the disease complex, have been encountered in 134 fields representing 20 counties.

Helminthosporium sativum and Fusarium roseum f. cerealis were the most commonly isolated. These two fungi induce similar symptoms on wheat and barley, both in the seedling and in the mature plant. They attack the subcrown internode and crown and basal-culm tissues, causing a brown discoloration and necrosis but occasion little damage to the roots.

These fungi are frequently found together in the same field, often in the same host plant. Forty per cent of the fields infested with Helminthosporium sativum were also infested with Fusarium. The former appears to be more important as a cause of seedling blight and the latter of root rot in later stages of plant growth.

Perithecia of Gibberella roseum $\mathrm{f}$. cerealis have been observed in the field only once, their absence probably being due to the low humidity at the season when temperatures are sufficiently high. The absence of wheat or barley scab in the state is explained by a lack of ascospore inoculum and by inadequate humidity at the time of heading. The absence of head blight, or kernel scabbing, in California offers a spectacular illustration of ecology in relation to plant disease.

Nonperithecium-producing clones of Fusarium roseum f. cerealis, such as the species formerly designated as $F$. culmorum var. leteius, are of importance only in soils of high organic content. Unlike the Gibberella-producing clones, they occasionally cause root rot of oats.

Take-all, caused by Ophiobolus graminis, is severe in certain areas on both wheat and barley. It has been located in 17 fields representing 7 counties. The root rot caused by this fungus is usually distinguishable from the others by the rotting of the roots, the shiny black discoloration of crown and lower- 
culm tissues, and the occurrence of a black mycelial mat between the lower leaf sheath and culm. Perithecia were not found under field conditions but formed abundantly on plants inoculated in the greenhouse.

Of the primary pathogenic fungi, Fusarium nivale is of least consequence and appears to be involved only in the adult root-rot stage in association with $\boldsymbol{F}$. roseum f. cerealis, Helminthosporium sativum, or both.

Three fungi-Pythium graminicolum, Sclerotium rolfsii, and Rhizoctonia solani-have been observed on occasion to cause root-rot damage in barley. $P$. graminicolum, under conditions of extremely high soil moisture, may bring about a reduction in stand and a severe weakening of the surviving plants. This situation has been encountered in two instances. Barley ordinarily is considered a good rotation crop for fields infested with $S$. rolfsii. In late-planted barley, however, with a combination of high temperature and adequate soil moisture (unseasonal rains or irrigation), this fungus may cause considerable root rot.

Wojnowicia graminis, Fusarium moniliforme, and some clones of $F$ : roseum, though commonly associated with root rots, have proved to be only weak parasites of secondary importance.

Of the saprophytic fungi associated with decaying cereal crown and root tissue, Fusarium oxysporum was most frequently encountered.

\section{LITERATURE CITED}

Dickson, JAMES G.

1923. Influence of soil temperature and moisture on the development of the seedlingblight of wheat and corn caused by Gibberella saubinetii. Jour. Agr. Res. 23:837-70

1946. Helminthosporium foot rot of barley. (Abstract) Phytopathology 36:397.

1947. Diseases of field crops. 429 p. McGraw-Hill Book Company, Inc., New York, N.Y. MACHACEK, J. E.

1943. An estimate of loss in Manitoba from common root rot in wheat. Sci. Agr. 24:70-77.

MACKIE, W. W.

1923. Foot-rot or Ophiobolus in California. Phytopathology 13:561-62.

1931. Diseases of grain and their control. California Agr. Exp. Sta. Bul. 511:1-87.

MCKINNEY, H. H.

1923. Influence of soil temperature and moisture on infection of wheat seedlings by $\mathrm{Hel}$ minthosporium sativum. Jour. Agr. Res. $26: 195-217$.

OsWaLd, JoHN W.

1947. Fungi causing root rots of cereals in California. (Abstract) Phytopathology 37: 845 .

1949. Cultural variation, taxonomy, and pathogenicity of Fusarium species associated with cereal root rots. Phytopathology $39: 359-76$.

Srmmonds, P. M.

1941. Root rots of cereals. Bot. Rev. 7:308-32.

SMITH, RALPH E.

1941. Diseases of field crops. California Agr. Ext. Serv. Cir. 121:1-79.

SNyder, William C., and H. N. Hansen.

1945. The species concept in Fusarium with reference to Discolor and other sections. Amer. Jour. Bot. 32:657-66.

SPRAGUE, RoDERICK.

1947. Rhizoctonia on field crops in the west. (Abstract) Phytopathology 37:846.

Suneson, Cort A., and JoHn W. Oswald.

1948. The effect of cereal crop rotation on "take-all" damage. (Abstract) Phytopathology 38:24-25.

Wollenweber, H. W., and O. A. Reinking.

1935. Die Fusarien. 355 p. Paul Parey, Berlin. 
The journal Hilgardia is published at irregular intervals, in volumes of about 600 pages. The number of issues per volume varies.

Subscriptions are not sold. The periodical is sent as published only to libraries, or to institutions in foreign countries having publications to offer in exchange.

You may obtain a single copy of any issue free, as long as the supply lasts; please request by volume and issue number from:

\section{Publications Office}

\section{College of Agriculture}

Berkeley 4 , California

The limit to nonresidents of California is 10 separate issues on a single order. A list of the issues still available will be sent on request. 